\title{
Carbon and Water in Upper Montane Soils and Their Influences on Vegetation in Southern Brazil
}

\author{
M. B. Scheer, ${ }^{1,2}$ G. R. Curcio, ${ }^{2}$ and C. V. Roderjan ${ }^{3}$ \\ ${ }^{1}$ Research and Development Assistance (APD/DMA), SANEPAR, Curitiba, PR, Brazil \\ ${ }^{2}$ Brazilian Agricultural Research Corporation (Embrapa Florestas), Colombo, PR, Brazil \\ ${ }^{3}$ Federal University of Paraná (UFPR), Curitiba, PR, Brazil
}

Correspondence should be addressed to M. B. Scheer; mauriciobs@sanepar.com.br

Received 25 November 2012; Accepted 3 January 2013

Academic Editors: P. Conte and W. Ding

Copyright (C) 2013 M. B. Scheer et al. This is an open access article distributed under the Creative Commons Attribution License, which permits unrestricted use, distribution, and reproduction in any medium, provided the original work is properly cited.

\begin{abstract}
Considering the many environmental functions of the upper montane soils, the aims of this study were (1) to verify if the soils of upper montane forests and grasslands of Caratuva Peak (1850 $\mathrm{m}$ a.s.l.) have similar characteristics to those found in other highlands in southern and southeastern Brazil; (2) to reinforce the geomorphological and pedological factors that impose the establishment of each type of vegetation in these highlands; and (3) to estimate potential soil carbon stocks and potential soil water retention. Folic and haplic histosols were found in the grasslands, and dystrophic regosols were found in the forests. The soils were dystrophic, extremely acidic, and saturated with $\mathrm{Al}$ and total organic carbon. In contrast to the grasslands, the upper montane forests were prevalent in valleys and subjected to morphogenetic processes resulting in soils that contained thicker mineral horizons. The grasslands occupied ridges and divergent convex ramps, and the pedogenetic processes in these regions promoted thicker histic horizons. The potential water retention capacities were high and strongly related to the high porosities of histic horizons associated with the gleyic horizons. In particularly, the carbon stocks were two- to three-fold higher than those found in soil ecosystems from the same latitude but lower altitude.
\end{abstract}

\section{Introduction}

Soil organic matter, which accumulates to a depth of 1 meter, weighs approximately $1500 \times 10^{15} \mathrm{~g}(\mathrm{Pg}=$ petagrams $)$ and constitutes the majority of continental organic carbon $[1,2]$. Considering the soil surrounding native vegetation, Brazil stocks $5 \%$ of the global carbon reservoir [1], indicating that a single country can significantly influence global carbon fluxes [3]. According to published studies [4-7], stock levels of below ground carbon increase concomitantly with higher altitudes. In southern Brazil, carbon stock levels of isolated soils can be two to three-fold greater in high altitudes compared to low altitudes from the same latitude [7].

Since the upper montane soil horizons include histic and humic horizons, they play an important role in the immobilization of carbon and regulation of hydric fluxes [810]. The vast accumulation of organic matter in these environments originates from a lack of decomposition by microbes owing to unfavorable conditions, such as low temperature, high humidity, low respiration, lack of available nutrients, and high exchangeable Al concentrations [9-11]. Moreover, the organic matter is highly humified and forms relatively stable organometallic complexes, predominantly with $\mathrm{Al}$ and $\mathrm{Fe}$ that serve as poor substrates for decomposition by microorganisms $[9,11-13]$.

The humic substances contribute to the sustainability of these ecosystems by increasing their nutrient contents and increasing their capacity for cation exchange and water retention. In turn, the ecosystem recycles carbon matter through above- and below-ground litterfall of developing vegetation $[9,10]$. During rainy periods, the upper montane soils minimize erosion by becoming waterlogged and draining slowly; thus, regulating the hydric fluxes to the headwaters of the river basins $[10,14,15]$. In dryer periods, upper montane soils collect water from horizontal precipitation (water present in clouds) that commonly occurs in upper montane forests 


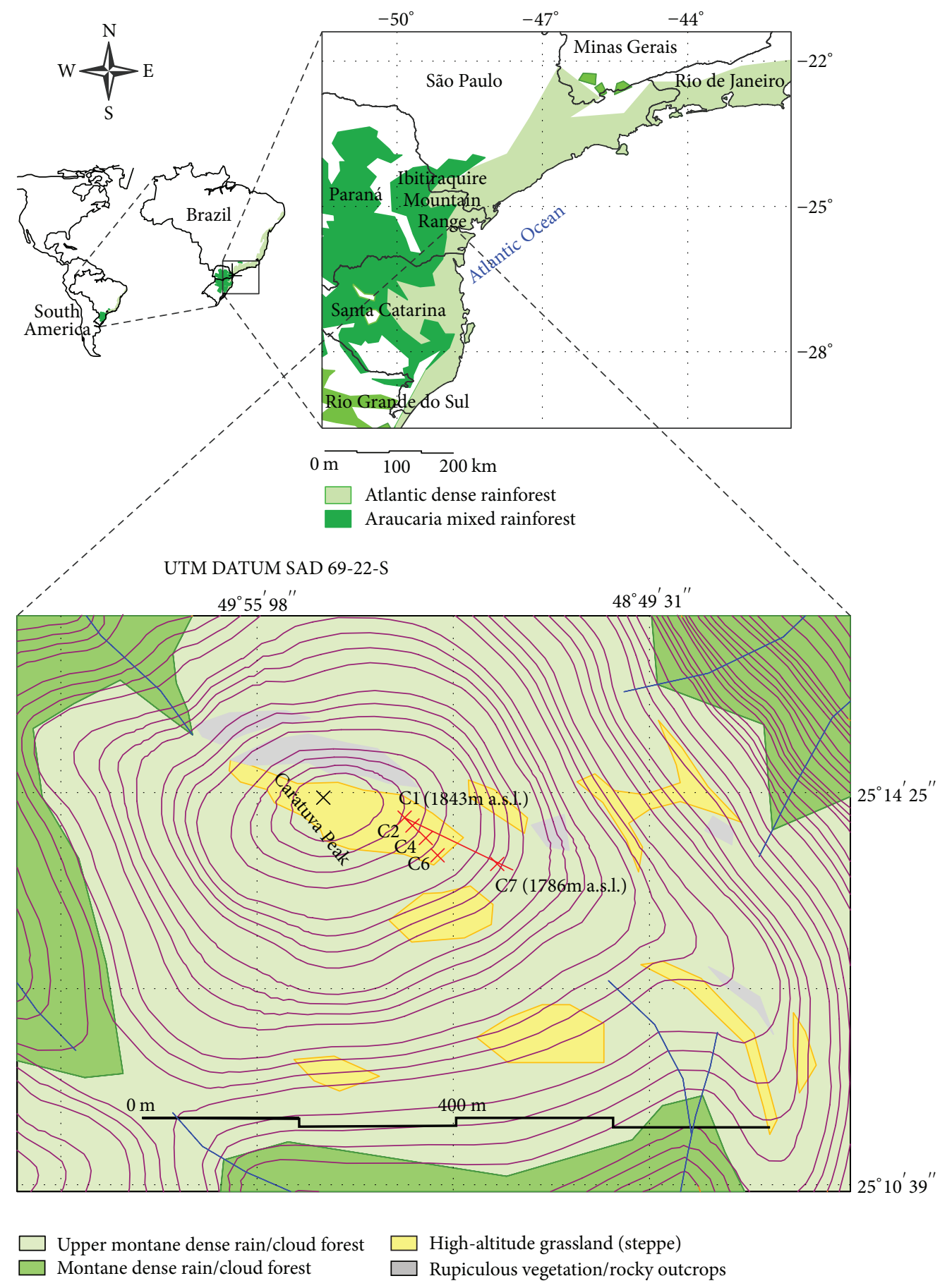

FIGURE 1: Sampling sequence in the Caratuva Peak, in the Ibitiraquire Mountain Range, southern Brazil.

$[14,15]$. This water can be retained by vegetation and soil or forwarded to the headwaters immediately downstream, thereby avoiding major losses.

Soil from the mountaintop regions of many upper montane environments has been developing for a few thousand years (some of them starting from the middle and late Holocene period). In this period, significant climate change promoted the invasion of forests on grasslands. Since then, these two types of vegetation have coexisted in a restricted landscape and are controlled by geomorphological features [7] forming the unique environment endemic to upper montane regions today.

Estimates of soil carbon stocks at regional, national, and global scales are important for the understanding of changes in carbon flux $[16,17]$. To improve our capacity for providing, promoting, and executing actions that mitigate 
the consequences of the global climate change related to the greenhouse gases, we need to acknowledge the importance of carbon stocks in different soil types and study the factors that influence their distribution $[3,16,18]$. Considering that a significant amount of organic matter is stocked in the surface of soil (up to $30 \mathrm{~cm}$ deep), there is a great risk of carbon dioxide liberation to the atmosphere when vegetation is burned, cut, or converted to support agriculture or livestock [17]. The loss of natural and soil ecosystems can have a significant economic impact [14]. Thus, the need to understand soil organic matter dynamics in different areas in the world is great [19].

Upper montane soils are still understudied $[3,6,9$, $20,21]$, and their importance is not yet fully appreciated [10]. In southern Brazil, some studies have characterized soils in upper montane rain/cloud forests [7, 22-28], but information about high altitude grassland soils is scarce $[7,27,28]$. According to previous studies conducted in the state of Paraná, southern Brazil, soils from grasslands and forests of upper montane ecosystems are undeveloped, extremely acidic, highly concentrated with carbon and have low base saturation and high exchangeable Al saturation. These observations are consistent with those reported in other upper montane regions of southeastern Brazil, which include different lithologies and vegetation types $[9,10,29]$ and upper montane cloud forests of Aparados da Serra Geral, in the state of Santa Catarina, also in southern Brazil [26]. Another important environmental function described for these soils is their high capacity for water retention (in some cases more than $500 \mathrm{~L} \mathrm{~m}^{2}$ ), which results from high total porosities of their histic and gleyic horizons [7].

Considering that studies about upper montane soils are very scarce, the aims of this study were (1) to verify if the soils of upper montane forests and grasslands of Caratuva Peak (1850 m a.s.l.) have similar characteristics to those found in other highlands of the mountain ranges in southern and southeastern Brazil, which vary in altitude; (2) to reinforce the geomorphological and pedological factors that impose the establishment of each type of vegetation in these highlands; and (3) to estimate potential soil carbon stocks and potential soil water retention.

\section{Material and Methods}

2.1. Study Area. The study area is located in Caratuva Peak (transect between 1840 and $1770 \mathrm{~m}$ a.s.l.). This is the second highest mountain of southern Brazil, located in the Ibitiraquire Mountain Range, a subrange of Serra do Mar (Sea Mountain Range) with coordinates $25^{\circ} 14^{\prime} \mathrm{S}$ and $48^{\circ} 49^{\prime} \mathrm{W}$ (Figure 1). The Caratuva Peak is within the Paraná Peak State Park, that spans parts of the municipalities of Antonina, Morretes, and Campina Grande do Sul.

Like most of the mountains in the sea mountain range of Paraná, their upper portions are formed by alkali granites embedded in high-grade metamorphic terrains with contacts clearly failing in keeping with their late to posttectonic origin [30]. According to Mineropar, intrusive, igneous rocks from Ibitiraquire Mountain Range (Graciosa granite) originated nearly 550 million years ago in the late pre-Cambrian to Cambrian period. It was cut by faults in the NE-SW axis by the Brasiliano (or Pan African) cycle (events of the end of the late Proterozoic) and the Ponta Grossa Arch, a major structure in the NW-SE basin of the Paraná River [31].

The upper parts of Ibitiraquire Mountain Range are covered with natural vegetation such as dense rain/cloud forests and grasslands (steppes). In the studied slope, the high-altitude grasslands are located near the summit, which lacks stony and rocky elements and is dominated by hydric divergence. The upper montane cloud forests occupy the crests downslope of the upper montane region and associated valleys with strong, undulating, and mountainous reliefs dominated by hydric convergence (Figure 2).

The Atlantic rainforest covers the greatest extension of Ibitiraquire Mountain Range, reaching the upper montane formation, with the highest part of the slopes reaching higher than $1830 \mathrm{~m}$ a.s.l. The majority of these forests are well preserved due to their isolation and difficult accessibility, despite some sites having been damaged by fires, such as other slopes of Caratuva Peak in 2007. In some slopes, located in the west, on the occidental side of the sea mountain range (at about $1300 \mathrm{~m}$ a.s.l.), there is an ecotonal zone between the Atlantic rainforest (Montane dense rainforest) and the Montane Araucaria forest. The high-altitude grasslands appear in the uppermost parts of the mountains, beginning from $1750 \mathrm{~m}$ a.s.l. in Caratuva Peak and from $1350 \mathrm{~m}$ a.s.l. in some other mountains. They are in excellent condition with no signs of human interference with the exception of mountain trails.

The sampling points were in a topographical sequence beginning near the sharp ridge of Caratuva Peak $(1850 \mathrm{~m}$ a.s.l) covered by high-altitude grasslands and dominated by Chusquea pinifolia (Nees) Ness (Poaceae; caratuva) with about $0.5 \mathrm{~m}$ height on histosols (according to World Reference Base for Soil Resources: FAO-WRB) in divergent, convex ramps. After an abrupt alteration in slope, the landscape changes to concave, converging ramps, with colluvionar stability that provide a $\mathrm{Cg}$ (gleyic) layer and a grassland/shrubland physiognomy to histosols ( $2.2 \mathrm{~m}$ height), which are also dominated by the caratuva. After another abrupt break of the slope (1790 $\mathrm{m}$ a.s.l.), the studied ramp gives rise to the upper montane cloud forest situated on mineral soils with a histic layer (Figures 1 and 2).

As previously commented, in the studied high-altitude grasslands, $C$. pinifolia is the dominant species, comprising at least $25 \%$ of the vegetation. In a survey of this physiognomy covering many mountains of the Ibitiraquire Mountain Range, 85 vascular plant species were found [32,33]. Additionally, Croton mullerianus L. R. Lima (Euphorbiaceae), Rhynchospora exaltata Kunth (Cyperaceae), Lagenocarpus triquetrus (Boeck.) Kuntze (Cyperaceae), and Machaerina austrobrasiliensis M. T. Strong are among the most important species. Tree species with extensive influence on the structure of the neighboring upper montane forests, of about $5 \mathrm{~m}$ in height, include Myrsine altomontana M.F. Freitas and Kin.-Gouv. (Myrsinaceae), Handroanthus catarinensis A. Gentry (Bignoniaceae), and Symplocos corymboclados Brand (Symplocaceae). These species also occur on the 


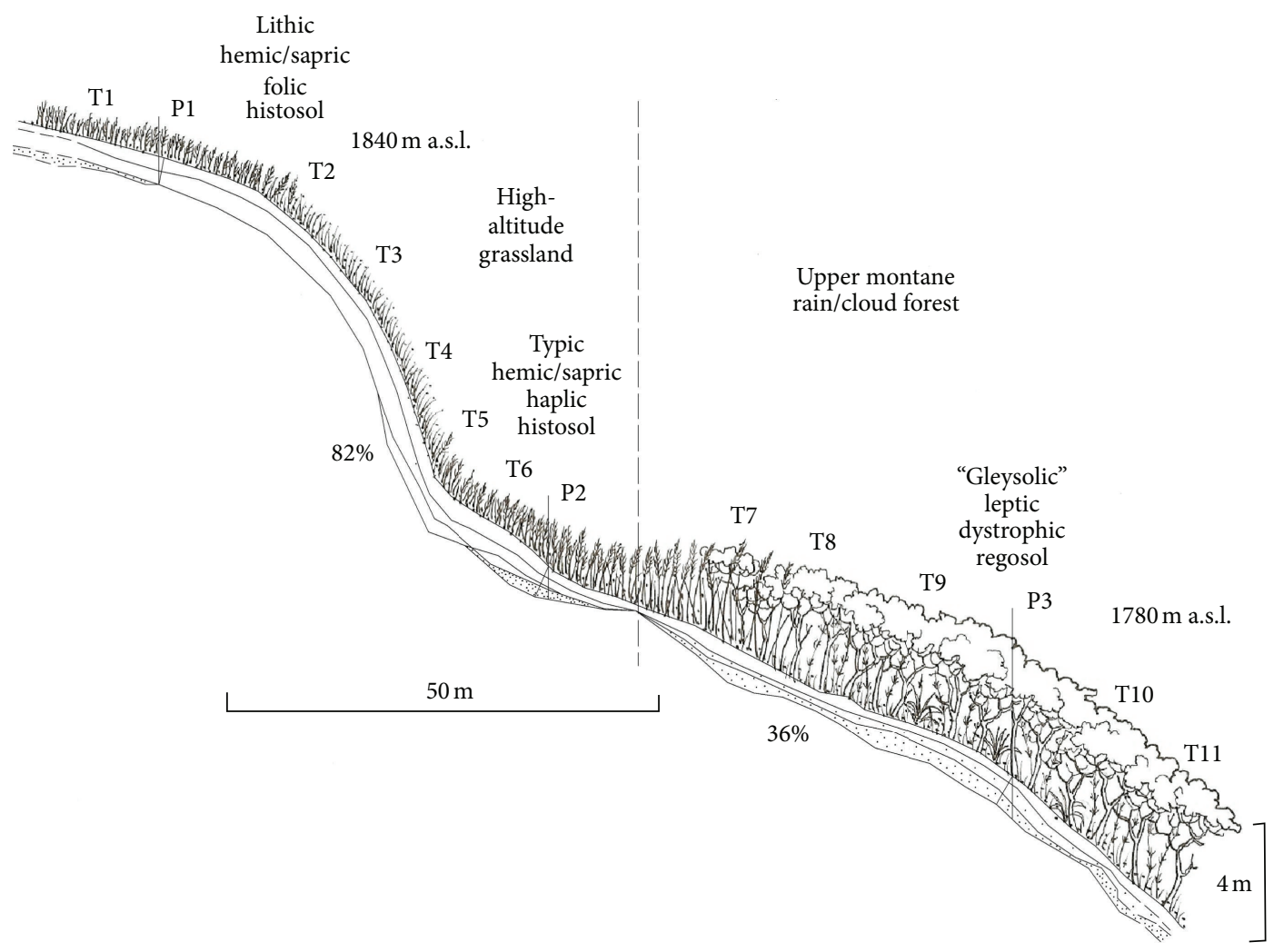

Histic horizons

Mineral horizons

FIGURE 2: Toposequence indicating the sampling points (auger $=\mathrm{T}$ and profiles $=\mathrm{P}$ ) in the Caratuva Peak, of the Ibitiraquire Mountain Range in southern Brazil.

grasslands, although sparsely, with low coverage, and in a shrub form, approximately $0.5 \mathrm{~m}$ in height, on the mountaintop grasslands with an average of $2.2 \mathrm{~m}$ height in the grasslands immediately downslope of the convergent ramps with higher colluvionar stability.

The change in vegetation from grassland to forest is abrupt, with a small ecotonal area with a shrubland physiognomy containing species of both formations in a range of 2 to 10 meters. According to $[34,35]$, Ilex microdontia Reisseck (Aquifoliaceae), Siphoneugena reitzii D. Legrand (Myrtaceae), Myrceugenia seriatoramosa (Kiaersk) D. Legrand and Kausel, and Drimys angustifolia Miers. (Winteraceae) contribute by $57.5 \%$ of the phytosociological importance $(\mathrm{PAP} \geq 10 \mathrm{~cm})$ of the sample sites in the Ibitiraquire Mountain Range, including the Caratuva Peak. The estimated basal area was $40.3 \mathrm{~m}^{2} \mathrm{ha}^{-1}$, and the tree density was $4600 \mathrm{ind} \mathrm{ha}^{-1}$.

The climate of upper portions of the sea mountain range of Paraná is classified as $\mathrm{Cfb}$ (subtropical), according to the Köppen classification system. It is predominantly wet, and the average temperature of the coldest month is between $-3^{\circ} \mathrm{C}$ and $18^{\circ} \mathrm{C}$, while the average temperature of the warmest month is below $22^{\circ} \mathrm{C}$ [22]. Roderjan and Grodski [36] observed an absolute minimum temperature of $-5^{\circ} \mathrm{C}$, an average annual temperature of $13.4^{\circ} \mathrm{C}$, and an absolute maximum temperature of $30^{\circ} \mathrm{C}$ at $1385 \mathrm{~m}$ a.s.l. in an upper montane forest at Anhangava Peak, approximately $24 \mathrm{~km}$ southwest of the Caratuva Peak. Based on the mean temperature variation of $0.56^{\circ} \mathrm{C}$ at each $100 \mathrm{~m}$ elevation, a mean temperature of $10.8^{\circ} \mathrm{C}$ can be estimated for the ridge of the Caratuva Peak. The precipitation in the sea mountain range is well distributed throughout the year and varies greatly depending on the local topography. Measurements in the coastal region exceed $2000 \mathrm{~mm}$ per year, and on the slopes of the mountains these values can reach $3500 \mathrm{~mm}$ [37].

2.2. Sample Collection and Data Analysis. The cores were carried out along a transect (toposequence), spanning high altitude grasslands and upper montane forests (Figures 1 and 2). After the soil survey, three profiles were analyzed, in which two of them represented the histosols of the grasslands and the regosols of the forests. Complementary superficial (0$20 \mathrm{~cm})$ and subsuperficial $(20-40 \mathrm{~cm})$ samples were collected with a hand auger. In these profiles, morphological descriptions and definition of the diagnostic horizons and samplings were done following Santos et al. [38], in order to classify the soils according to the Brazilian Soil Classification System [39]. The Von Post scale [39] was used to classify the stage of decomposition of organic matter in the field.

Physicochemical analyses were based on air-dried soil, and granulometric analysis was carried out according to 
the densitometer method [40]. Due to the limitation of the laboratorial procedure for histic material, only the clay fractions for the majority of the samples were obtained. The chemical and physicohydric analyses were performed according to published reports [40]. The potential water retention capacities were estimated by the volumetric humidity and calculated by the subtraction of the aeration porosity from the total porosity [41]. Data were reported by units of $\mathrm{L} \mathrm{m}^{-2}$ and $\mathrm{m}^{3} \mathrm{ha}^{-1}$ according to the thicknesses of the horizons.

The total organic carbon (TOC) analyzed by dry weight method was done in Stable Isotope Laboratory of the Center for Nuclear Energy in Agriculture, Brazil (Table 1). Soil carbon stocks $\left(\mathrm{kg} \mathrm{C} \mathrm{m}^{-2}\right)$ were calculated according to Batjes [1] and Yimer et al. [17]. First, the TOC $\left(\mathrm{g} \mathrm{kg}^{-1}\right)$ of each horizon was multiplied by the soil density $\left(\mathrm{kg} \mathrm{m}^{-3}\right)$ and by its thickness (in $\mathrm{m}$ ). The density of course particles ( $\geq 2 \mathrm{~mm}$ ), generally subtracted from the soil density to use only the fraction $\leq 2 \mathrm{~mm}[13,19]$ was a variable not necessary due to its negligible values. Data were reported by units of $\mathrm{MgCha}^{-1}$. The stocks of $\mathrm{C}$ of all points of the transect were based on their thicknesses and on the correspondent concentrations and densities of the nearest profiles.

The Ibitiraquire Mountain Range has an estimated 790 ha of high-altitude grasslands [44]. The soil C stocks were estimated for these ecosystems as an approach to predict their magnitude. The soil $\mathrm{C}$ stocks for the upper montane ecosystems, including both the grasslands and forests of Sea Mountain Range in Paraná were estimated based on the areas calculated by PRÓ-ATLÂNTICA [45]. However, we emphasize that in this study only the potential soil C stocks were estimated. Further estimations on scales of greater detail and consideration of additional types of soils present in other portions of the mountains are needed.

To compare chemical properties among the main horizons of 0 to $20 \mathrm{~cm}$ and 20 to $40 \mathrm{~cm}$ and the soil C stocks of the studied grasslands and forests, Kruskal Wallis tests $(P<0,05)$ were performed. Spearman correlation coefficients $\left(R_{s}\right)$ were calculated to verify the behavior of the chemical parameters along profile depths.

\section{Results and Discussion}

3.1. High-Altitude Grassland Soils in Caratuva Peak. A predominance of histosols in the high-altitude grasslands in Caratuva Peak was observed. The histic horizons (mainly "O", humid colors 10YR 3/3 and N2/) presented with high concentrations of TOC $\left(400 \mathrm{~g} \mathrm{~kg}^{-1}\right)$. Profile 1 (nearer to the ridge) was classified as "lithic hemic/sapric folic histosol" and profile 2 (about $100 \mathrm{~m}$ downslope) as "typic/hemic sapric haplic histosol". The first profile was comprised of seasonal hydromorphic soil (O and $\mathrm{O} 2 / \mathrm{H}$ horizons) and its location in a divergent convex slope, was more drained than profile 2 (Table 1 and Figure 3(a)). In the haplic histosol (less drained than the upslope folic histosols), three subhorizons were identified including two histic $(\mathrm{O}$ and $\mathrm{H})$ and one mineral $(\mathrm{Cg})$. The mineral subhorizon was not considered to be a terric histosol because it had a medium texture and was found to be less than $30 \mathrm{~cm}$ thick in the $1 \mathrm{~m}$ depth of soil surveyed.
This reducing environment was influenced by its position within a divergent concave slope (near the end of the ramp) combined with the low saturated permeability of the deepest mineral horizons, which delay the run off of the system (Table 3). Both soils had a prevalence of hemic herbaceous materials in topsoil.

The characteristics of these extremely acidic soils are similar to those found in other high-altitude grasslands of the Sea Mountain Range in southern Brazil $[7,27,28]$ and those studied in soils associated with rocky outcrops in Mantiqueira Mountain Range in southeastern Brazil [9, 10, 46, 47]. The $\mathrm{Al}, m \%$ (aluminum saturation) and cation exchange capacity (CEC) of the histic horizons increased with depth $\left(R_{s}=1\right.$; $P<0.01$; Tables 1 and 2). This was due to the mineral fraction (mainly clay) in the system. The bases of the histic horizons ( $S=$ sum of bases) were probably drained in relation to depth of values of three- to sixfold lower than on the surface (Tables 1 and 2). The $\mathrm{P}$ concentrations were considered to be in the low to medium range [48], and the base saturation (BS\%), very low in topsoil, decreased proportionally with $\operatorname{depth}\left(R_{s}=-1 ; P<0,01\right.$; Tables 1 and 2$)$.

3.2. Upper Montane Rain/Cloud Forest in Caratuva Peak. In the third part of the toposequence downslope, the soil was classified as "gleysolic leptic dystrophic regosol" (Tables 1 and 2; Figure 3(c)). The histic horizon (10YR 2/1) was less than $40 \mathrm{~cm}$ thick and had high TOC $\left(421 \mathrm{~g} \mathrm{~kg}^{-1}\right.$, Table 3). Below, two mineral horizons were observed, Big (10YR 5/2) and C (10YR 5/4), both with "mottles" in color (10YR 5/7). Due to the geomorphic position, the soils observed were "shallow" according to EMBRAPA (2006). The Big horizon signified the action of hydric fluxes. The "concave convergent" slope in "strong undulated" relief permitted the formation of mineral horizons through the combined action of morphogenetic (colluvium) and pedogenetic processes. These extremely acidic soils also presented with low base saturation, consistent with those found in other upper montane soils [7, 22-28].

As compared to the study by Scheer et al. [7], which was conducted in a mountain range $41 \mathrm{~km}$ south of our study site, the organic horizons of the upper montane soils in Caratuva Peak contained higher exchangeable base P concentrations, CEC, and potential acidity than the mineral horizons (Tables 1 and 2). CEC and acidity were due to the $\mathrm{H}^{+}$ions from the carboxylic and phenolic groups of the organic matter $[9,11]$. The base of the desaturated Big horizon presented with high Al saturation (alitic character), suggesting that it was part of the forest cycle between the histic horizon and the litter. According to the literature, regosols have yet to be found and described in upper montane environments in southern Brazil.

3.3. Common Characteristics of Upper Montane Soils. The low fertility rates observed in vegetation of upper montane landscapes are related to the loss of nutrients caused by leaching from high rainfall amounts (horizontal precipitation, [15, $49]$ ), in addition to generally low nutrient concentrations afforded by parental material [10]. According to these authors, 
TABLE 1: Soil properties of the upper montane ecosystems in Caratuva, southern Brazil.

\begin{tabular}{|c|c|c|c|c|c|c|c|c|c|c|c|c|c|c|c|}
\hline Horizon & $\begin{array}{l}\text { Depth. } \\
\mathrm{cm}\end{array}$ & Color & $\begin{array}{c}\mathrm{pH} \\
\mathrm{CaCl}_{2}\end{array}$ & $\mathrm{Al}^{+3}$ & $\mathrm{H}^{+}+\mathrm{Al}^{+3}$ & $\begin{array}{l}\mathrm{Ca}^{+2} \\
\mathrm{Cmol}_{\mathrm{c}}\end{array}$ & $\begin{array}{l}\mathrm{Mg}^{+2} \\
\mathrm{dm}^{-3}\end{array}$ & $\mathrm{~K}^{+}$ & S & CEC & $\begin{array}{c}\mathrm{P} \\
\mathrm{mg} \mathrm{dm} \\
\end{array}$ & $\begin{array}{c}\text { BS } \\
\%\end{array}$ & $\begin{array}{l}m \\
\%\end{array}$ & $\mathrm{Ca} / \mathrm{Mg}$ & $\begin{array}{c}{ }^{*} \text { Factor } \mathrm{cmol}_{\mathrm{c}} \mathrm{dm}^{-3} \text { to } \\
\mathrm{cmol}_{\mathrm{c}} \mathrm{kg}^{-1}\end{array}$ \\
\hline \multicolumn{16}{|c|}{ Profile 1: grassland: lithic hemic/sapric folic histosol } \\
\hline $\mathrm{O} 1$ & $0-20$ & $10 Y R 3 / 3$ & 3.3 & 1.4 & 22.5 & 1.5 & 1.3 & 0.6 & 3.4 & 25.9 & 13.0 & 13 & 29 & 1.2 & 2.6 \\
\hline $\mathrm{O} 2$ & $20-30$ & $\mathrm{~N} 2 /$ & 2.9 & 13.1 & 57.0 & 0.5 & 0.2 & 0.1 & 0.8 & 57.8 & 3.8 & 1 & 94 & 2.5 & 2.0 \\
\hline \multicolumn{16}{|c|}{ Profile 2: grassland: typic hemic/sapric haplic histosol } \\
\hline O1 & $0-20$ & $10 Y R 3 / 3$ & 3.1 & 1.8 & 29.3 & 0.7 & 0.8 & 0.5 & 2.0 & 31.3 & 13.9 & 6 & 48 & 0.9 & 2.6 \\
\hline $\mathrm{O} 2$ & $22-49$ & & 3.0 & 3.6 & 45.5 & 0.2 & 0.2 & 0.1 & 0.5 & 46.0 & 9.2 & 1 & 87 & 1.0 & 2.6 \\
\hline $\mathrm{H} 1$ & $49-55$ & & 2.9 & 15.2 & 53.0 & 0.2 & 0.1 & 0.02 & 0.3 & 53.3 & 3.8 & 1 & 98 & 2.0 & 2.0 \\
\hline $\mathrm{Cg}$ & $55-70$ & & 3.4 & 7.4 & 19.0 & 0.2 & 0.1 & 0.05 & 0.4 & 19.4 & 3.2 & 2 & 95 & 2.0 & 1.0 \\
\hline \multicolumn{16}{|c|}{ Profile 3: forest: "gleysolic" leptic dystrophic regosol } \\
\hline $\mathrm{O}$ & $0-15$ & 10YR 2/1 & 2.6 & 3.1 & 41.6 & 0.4 & 0.6 & 0.3 & 1.3 & 42.9 & 16.6 & 3 & 70 & 0.7 & 2.7 \\
\hline Big & $15-28$ & 10 YR $5 / 2$ & 3.4 & 2.7 & 9.7 & 0.1 & 0.1 & 0.05 & 0.3 & 10.0 & 2.2 & 3 & 92 & 1.0 & 1.0 \\
\hline $\mathrm{C}$ & $28-57$ & $\begin{array}{c}\text { 10YR 5/4 } \\
\text { (mottles) 10YR } \\
5 / 7\end{array}$ & 3.9 & 2.1 & 8.4 & 0.2 & 0.1 & 0.04 & 0.3 & 8.7 & 1.2 & 4 & 86 & 2.0 & 1.0 \\
\hline
\end{tabular}

* Transforming factor from $\mathrm{cmol}_{\mathrm{c}} \mathrm{dm}^{-3}$ to $\mathrm{cmol}_{\mathrm{c}} \mathrm{kg}^{-1}$ calculated based on the inverse of the density of the prepared sample for the analysis of each horizon.

TABLE 2: Chemical properties of the soil horizons of the upper montane ecosystems in Caratuva Peak $(n=2-6)$. Values in parentheses represent the standard errors.

\begin{tabular}{|c|c|c|c|c|c|c|c|c|c|c|c|c|c|c|}
\hline Horizon & $\begin{array}{c}\text { Depth } \\
\text { (average) } \\
\mathrm{cm}\end{array}$ & $\begin{array}{c}\mathrm{pH} \\
\mathrm{CaCl}_{2} \\
\end{array}$ & $\mathrm{Al}^{+3}$ & $\mathrm{H}^{+}+\mathrm{Al}^{+3}$ & $\begin{array}{l}\mathrm{Ca}^{+2} \\
\mathrm{~cm} \\
\end{array}$ & $\begin{array}{c}\mathrm{Mg}^{+2} \\
\mathrm{ol}_{\mathrm{c}} \mathrm{dm}^{-} \\
\end{array}$ & $\mathrm{K}^{+}$ & S & CEC & $\begin{array}{c}\mathrm{P} \\
\mathrm{mg} \mathrm{dm}{ }^{-3}\end{array}$ & $\begin{array}{l}\text { BS } \\
\% \\
\end{array}$ & $\begin{array}{l}m \\
\% \\
\end{array}$ & $\mathrm{Ca} / \mathrm{Mg}$ & $\begin{array}{c}{ }^{*} \text { Factor } \mathrm{cmol}_{\mathrm{c}} \mathrm{dm}^{-3} \text { to } \\
\mathrm{cmol}_{\mathrm{c}} \mathrm{kg}^{-1}\end{array}$ \\
\hline \multicolumn{15}{|c|}{ Grassland: histosols } \\
\hline $\begin{array}{l}\mathrm{O} 1 \\
n=6\end{array}$ & $0-20$ & $\begin{array}{l}3.2 \mathrm{a} \\
(0.1)\end{array}$ & $\begin{array}{l}1.5 b \\
(0.1)\end{array}$ & $\begin{array}{l}27.7 \mathrm{~b} \\
(2.4)\end{array}$ & $\begin{array}{l}0.9 \mathrm{a} \\
(0.2)\end{array}$ & $\begin{array}{l}0.9 \mathrm{a} \\
(0.1)\end{array}$ & $\begin{array}{l}0.47 \mathrm{a} \\
(0.0)\end{array}$ & $\begin{array}{l}2.3 \mathrm{a} \\
(0.3)\end{array}$ & $\begin{array}{c}26.6 \mathrm{~b} \\
(1.7)\end{array}$ & $\begin{array}{l}15.6 \mathrm{a} \\
(1.5)\end{array}$ & $\begin{array}{l}8.0 \mathrm{a} \\
(1.2)\end{array}$ & $\begin{array}{l}40.2 \mathrm{a} \\
(4.4)\end{array}$ & $\begin{array}{l}1.0 \mathrm{a} \\
(0.2)\end{array}$ & 2.6 \\
\hline $\begin{array}{l}\mathrm{O} 2 \\
n=6\end{array}$ & $20-40$ & $\begin{array}{c}3.1 \mathrm{a} \\
(0.0)\end{array}$ & $\begin{array}{l}7.1 \mathrm{a} \\
(1.7)\end{array}$ & $\begin{array}{c}46.8 \mathrm{a} \\
(2.1)\end{array}$ & $\begin{array}{l}0.3 \mathrm{~b} \\
(0.1)\end{array}$ & $\begin{array}{l}0.2 \mathrm{~b} \\
(0.0)\end{array}$ & $\begin{array}{l}0.1 \mathrm{~b} \\
(0.0)\end{array}$ & $\begin{array}{l}0.6 \mathrm{~b} \\
(0.1)\end{array}$ & $\begin{array}{l}47.4 \mathrm{a} \\
(2.2)\end{array}$ & $\begin{array}{l}7.7 \mathrm{~b} \\
(1.6)\end{array}$ & $\begin{array}{l}1.2 \mathrm{~b} \\
(0.2)\end{array}$ & $\begin{array}{c}90.2 \mathrm{~b} \\
(2.0)\end{array}$ & $\begin{array}{l}1.2 \mathrm{a} \\
(0.3)\end{array}$ & 2.6 \\
\hline $\begin{array}{l}\mathrm{O} 3 / \mathrm{H} \\
n=3\end{array}$ & $40-55$ & $\begin{array}{l}3.1 \mathrm{a} \\
(0.1)\end{array}$ & $\begin{array}{l}9.9 \mathrm{a} \\
(2.7)\end{array}$ & $\begin{array}{c}43.5 \mathrm{ab} \\
(6.1)\end{array}$ & $\begin{array}{c}0.17 \mathrm{~b} \\
(0.03)\end{array}$ & $\begin{array}{c}0.17 \mathrm{~b} \\
(0.07)\end{array}$ & $\begin{array}{l}0.07 b \\
(0.04)\end{array}$ & $\begin{array}{l}0.4 \mathrm{~b} \\
(0.1)\end{array}$ & $\begin{array}{c}43.9 \mathrm{ab} \\
(6.2)\end{array}$ & $\begin{array}{l}6.03 \mathrm{~b} \\
(1.24)\end{array}$ & $\begin{array}{l}1.0 \mathrm{~b} \\
(0.0)\end{array}$ & $\begin{array}{c}95.7 \mathrm{~b} \\
(1.4)\end{array}$ & $\begin{array}{l}1.2 \mathrm{a} \\
(0.4)\end{array}$ & 2.7 \\
\hline $\begin{array}{l}\mathrm{Cg} \\
n=2\end{array}$ & $55-70$ & 3.5 & 7.25 & 19.70 & 0.15 & 0.10 & 0.05 & 0.30 & 20.00 & 4.45 & 1.50 & 96.00 & 1.50 & 1.0 \\
\hline \multicolumn{15}{|c|}{ Forest: regosols and gleysols } \\
\hline $\begin{array}{l}\text { O1 } \\
n=5\end{array}$ & $0-20$ & $\begin{array}{l}2.9 \mathrm{~b} \\
(0.2)\end{array}$ & $\begin{array}{l}2.3 \mathrm{a} \\
(0.3)\end{array}$ & $\begin{array}{l}35.9 \mathrm{a} \\
(2.5)\end{array}$ & $\begin{array}{c}0.7 \mathrm{a} \\
(0.3)\end{array}$ & $\begin{array}{l}1.0 \mathrm{a} \\
(0.2)\end{array}$ & $\begin{array}{l}0.46 a \\
(0.0)\end{array}$ & $\begin{array}{l}2.1 \mathrm{a} \\
(0.5)\end{array}$ & $\begin{array}{l}38.0 \mathrm{a} \\
(2.5)\end{array}$ & $\begin{array}{c}26.0 \mathrm{a} \\
(2.9)\end{array}$ & $\begin{array}{l}5.4 \mathrm{a} \\
(1.2)\end{array}$ & $\begin{array}{c}53.6 \mathrm{~b} \\
(6.9)\end{array}$ & $\begin{array}{l}0.6 \mathrm{a} \\
(0.2)\end{array}$ & 2.7 \\
\hline $\begin{array}{l}\text { Cg1/Big } \\
n=5\end{array}$ & $20-40$ & $\begin{array}{l}3.4 \mathrm{a} \\
(0.2)\end{array}$ & $\begin{array}{l}3.7 \mathrm{a} \\
(0.5)\end{array}$ & $\begin{array}{l}13.6 \mathrm{~b} \\
(1.6)\end{array}$ & $\begin{array}{c}0.1 b \\
(0.0)\end{array}$ & $\begin{array}{l}0.1 \mathrm{~b} \\
(0.0)\end{array}$ & $\begin{array}{c}0.05 b \\
(0.0)\end{array}$ & $\begin{array}{l}0.3 \mathrm{~b} \\
(0.0)\end{array}$ & $\begin{array}{c}13.9 \mathrm{~b} \\
(1.6)\end{array}$ & $\begin{array}{l}2.4 \mathrm{~b} \\
(0.2)\end{array}$ & $\begin{array}{l}2.2 \mathrm{~b} \\
(0.4)\end{array}$ & $\begin{array}{l}92.8 \mathrm{a} \\
(0.9)\end{array}$ & $\begin{array}{l}1.2 \mathrm{a} \\
(0.2)\end{array}$ & 1.0 \\
\hline $\begin{array}{l}\text { C } \\
n=2\end{array}$ & $40-60$ & 3.8 & 3.2 & 11.3 & 0.2 & 0.1 & 0.05 & 0.4 & 11.6 & 1.5 & 3.0 & 89.0 & 2.0 & 1.0 \\
\hline
\end{tabular}

*Transforming factor from $\mathrm{cmol}_{\mathrm{c}} \mathrm{dm}^{-3}$ to $\mathrm{cmol}_{\mathrm{C}} \mathrm{kg}^{-1}$ calculated based on the inverse of the density of the prepared sample for the analysis of each horizon. Averages followed by the same letter in vertical correspond the medians that do not differ statistically by the Kruskall-Wallis test $(P<0.05)$.

acidity favors the dissolution of kaolinite and aluminosilicates, while the Al saturates the exchange complex. Therefore, nutrient cycling is essential because it leads to higher amounts of nutrients in superficial organic horizons [10] through their retention in high-density roots $[9,11]$, which increase the efficiency of hydrosoluble absorption [7]. Although the upper montane soils contained high Al saturation, considerable amounts of this element complexed with organic matter.
Therefore, its concentration was controlled in the soil solution, and toxicity to plants was avoided $[9,11,13,50,51]$.

The genesis occurred in seasonal hydromorfisms of these soils was controlled by the elevated altitudes, facilitating cloud formation, lower temperatures, higher storage of organic matter by the low mineralization rate [24], and high rainfall amounts. The accumulation of organic matter surpassed the decomposition rate, because despite the existence 
TABle 3: Physicohydrical properties of soil in profiles in Caratuva Peak $(n=2)$.

\begin{tabular}{|c|c|c|c|c|c|c|c|c|c|c|c|}
\hline \multirow[t]{2}{*}{ Horizon } & \multirow{2}{*}{$\begin{array}{l}\text { hickness } \\
\mathrm{cm}\end{array}$} & \multirow{2}{*}{$\begin{array}{c}\begin{array}{c}\text { Clay/silt/ } \\
\text { sand }\end{array} \\
\mathrm{g} \mathrm{kg}^{-1}\end{array}$} & \multicolumn{3}{|c|}{ Porosity (\%) } & \multirow{2}{*}{$\begin{array}{c}\text { Available water } \\
(\%)\end{array}$} & \multirow{2}{*}{$\begin{array}{c}\text { Saturated } \\
\text { permeability } \\
\mathrm{cm} \mathrm{h}^{-1}\end{array}$} & \multirow{2}{*}{$\begin{array}{c}\text { TOC } \\
\% \\
\end{array}$} & \multirow{2}{*}{$\begin{array}{c}\text { Soil } \\
\text { density } \\
\mathrm{kg} \mathrm{m}^{-2}\end{array}$} & \multirow{2}{*}{$\begin{array}{l}\text { C stock } \\
\mathrm{kg} \mathrm{m}^{-2}\end{array}$} & \multirow{2}{*}{$\begin{array}{l}\text { Potential water } \\
\text { retention } \\
\text { capacity } \\
\mathrm{L} \mathrm{m}^{-2}\end{array}$} \\
\hline & & & Total & Macro & Aeration & & & & & & \\
\hline \multicolumn{12}{|c|}{ Profile 1: grassland: lithic hemic/sapric folic histosol } \\
\hline $\mathrm{O} 1$ & 20 & 175 & 98.4 & 35.1 & 37.5 & 5.8 & 319.5 & 41.9 & 0.117 & 9.80 & 121.8 \\
\hline $\mathrm{O} 2 / \mathrm{H}$ & 10 & 200 & 95.8 & 12.1 & 12.8 & 5.2 & 0.3 & 40.9 & 0.238 & 9.73 & 83.0 \\
\hline Total & - & - & - & - & - & - & - & - & - & 19.54 & 204.8 \\
\hline \multicolumn{10}{|c|}{ Average plus standard errors extrapolating to all sampling points $(n=3)$} & $(26.1 \pm 3.3)$ & $(338.2 \pm 8.5)$ \\
\hline \multicolumn{12}{|c|}{ Profile 2: grassland: typic hemic/sapric haplic histosol } \\
\hline $\mathrm{O} 1$ & 22 & 100 & 99.9 & 34.4 & 35.3 & 7.4 & 158.2 & 42.3 & 0.108 & 10.05 & 142.1 \\
\hline $\mathrm{O} 2$ & 27 & 125 & 98.3 & 12.6 & 13.5 & 5.7 & 36.2 & 37.9 & 0.133 & 13.61 & 229.0 \\
\hline $\mathrm{H}$ & 6 & 125 & 87.3 & 9.6 & 10.2 & 7.3 & 3 & 20.8 & 0.302 & 3.77 & 46.3 \\
\hline $\mathrm{Cg}$ & 15 & 125 & $62.8^{*}$ & $9.2^{*}$ & $9.3^{*}$ & $5.3^{*}$ & $7.2^{*}$ & $1.37^{*}$ & $1.089^{*}$ & 2.24 & 80.3 \\
\hline Total & - & - & - & - & - & - & - & - & - & 29.67 & 497.6 \\
\hline \multicolumn{10}{|c|}{ Average plus standard errors extrapolating to all sampling points $(n=3)$} & $(46.3 \pm 2.7)$ & $(565.6 \pm 7.7)$ \\
\hline \multicolumn{12}{|c|}{ Profile 3: forest: "gleysolic" leptic dystrophic regosol } \\
\hline $\mathrm{O}$ & 15 & 138 & 99.2 & 34.8 & 36.4 & 6.6 & 238.9 & 42.1 & 0.113 & 7.10 & 94.1 \\
\hline Big & 13 & 125 & 62.8 & 9.2 & 9.3 & 5.3 & 7.2 & 1.37 & 1.089 & 1.94 & 69.6 \\
\hline $\mathrm{C}$ & 29 & 125 & $62.8^{*}$ & $9.2^{*}$ & $9.3^{*}$ & $5.3^{*}$ & $7.2^{*}$ & $1.37^{*}$ & $1.089^{*}$ & 4.33 & 155.2 \\
\hline Total & - & & - & - & - & - & - & - & - & 13.37 & 318.8 \\
\hline \multicolumn{10}{|c|}{ Average plus standard errors extrapolating to all sampling points $(n=5)$} & $(15.9 \pm 2.5)$ & $(398.8 \pm 8.9)$ \\
\hline
\end{tabular}

*Values estimated based on horizons with similar characteristics.

${ }^{* *}$ Limited estimates for granulometric analysis due to the high organic matter concentrations.

of concurrent biological transformation, humified organic carbon was highly preserved [23].

3.4. What Can Explain the Occurrence of Forest or Grasslands in Upper Montane Environments? According to studies carried out in high-altitude grasslands of southern Brazil, the histosols and histic entisols are the most common soils [7]. Both soils contained histic horizons without mineral horizons or without their presence at $40 \mathrm{~cm}$ depth. Histic horizons between 20 to $40 \mathrm{~cm}$ deep that lacked mineral horizons (also known as a histosol, according to the Brazilian Classification, EMBRAPA [39]), seem to suppress the establishment of trees taller than $1 \mathrm{~m}$ [7]. Together, the depth of histic horizons (in some cases $>50 \mathrm{~cm}$ ), their low global densities, the high density of roots from typic grassland species, and the exposure of mountaintops to strong winds constitute conditions that are refractory to the growth and establishment of large trees that could promote the advancement of upper montane forests over grasslands as suggested previously [7] and reinforced by our data. However, lithic folic histosols (histic horizons between 20 and $35 \mathrm{~cm}$ deep) and histic litholic entisols (histic horizons $<20 \mathrm{~cm}$ ) were identified by Roderjan [22] and Rocha [24] in upper montane cloud forests. Despite being stunted (low stature, high density, and low basal area), these forests were classified as dwarf forests.

Future climate changes affecting rainfall levels may result in the disappearance of grasslands through considerable loss of area to forests or erosion of histic horizons caused by oxidation [7]. Other areas must be investigated to know whether the forests have already reached the maximum limit of expansion on the high-altitude grasslands of the Sea Mountain Range [7]. Studies of soils associated with highaltitude rocky complexes in southeastern Brazil [10] revealed that some peatlands (histosols) can dry sufficiently by a drainage system, leading to a forest growth but maintaining the large stocks of carbon. In addition to climate change, the fragility of upper montane ecosystems is challenged by the impact of human activity at nearby hiking trails and camping sites. The mountain range of Caratuva Peak (Paraná Peak State Park) attracts many visitors, and, in dryer periods, the environment has a high susceptibility to anthropic fires and a high risk of loss of these ecosystems [7].

The chemical composition of histic horizons below the depth of $20 \mathrm{~cm}$ depth at high-altitude grasslands was remarkably different from mineral horizons found at the same depth in soils of upper montane forests (Tables 1 and 2). Previously, other soils with relatively low densities and high basal areas were observed in upper montane rain/cloud forests in southern Brazil including cambisols [22, 24], argisols [24], and gleysols [7, 24] in valleys and peaks with higher colluvium. Upper montane forests in (typic humic and typic dystrophic) entisols were studied by Roderjan [22], Portes [25], and Vashchenko et al. [28]. The mineral horizons (A humic and C) of these soils as well as Big and $\mathrm{C}$ of regosols observed in Caratuva Peak seemed to promote higher mechanical 


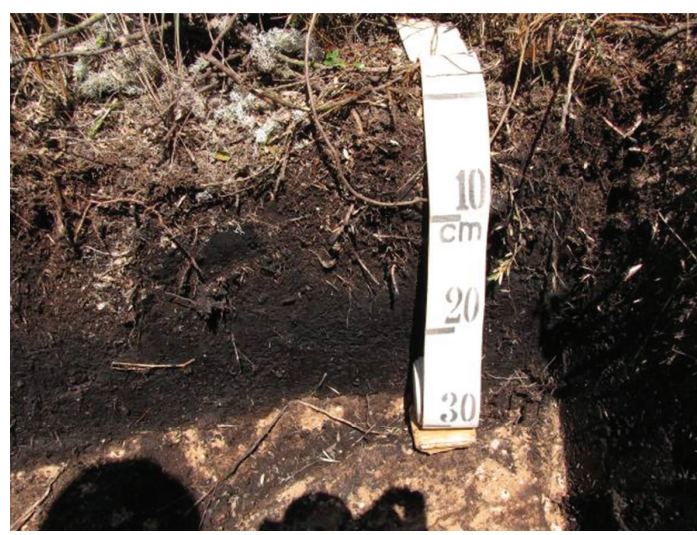

(a)

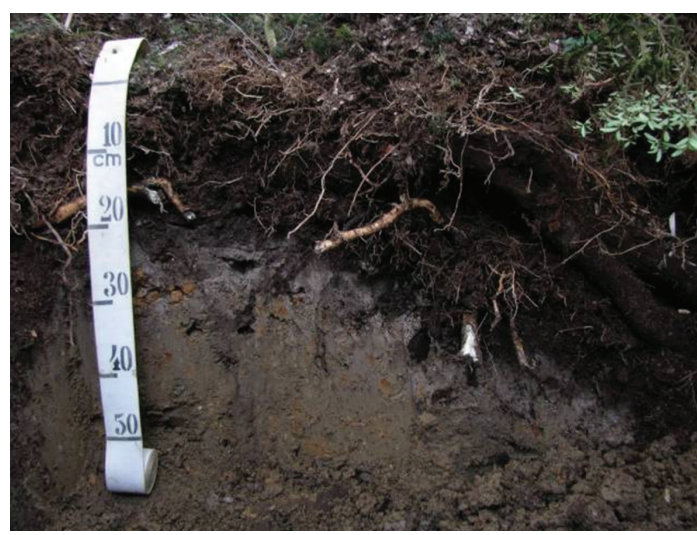

(c)

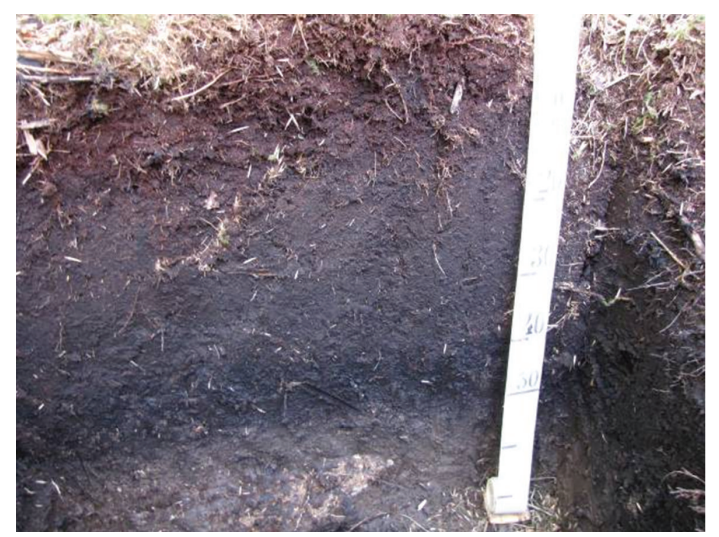

(b)

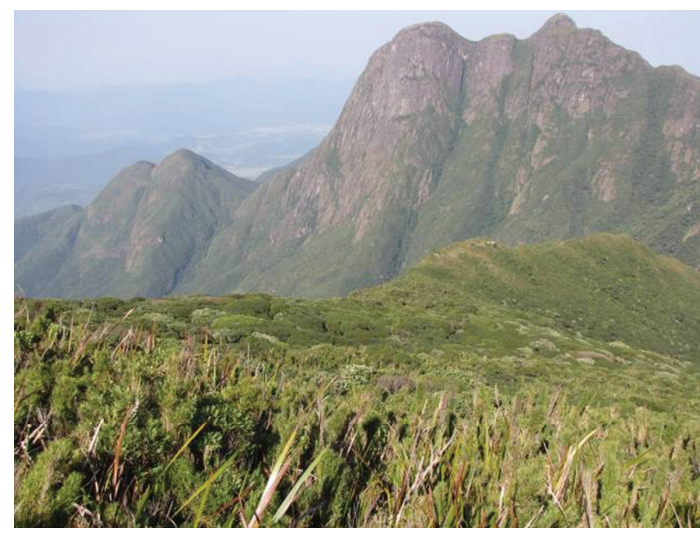

(d)

Figure 3: (a) Profile 1: histosol in high-altitude grassland near to the ridge of Caratuva Peak. (b) Profile 2: histosol in high-altitude grassland nearer to the grassland-forest ecotone. (c) Profile 3: regosol in upper montane rain/cloud forest. (d) Toposequence in Caratuva Peak (foreground). At the bottom, Paraná Peak, southern Brazil.

aggregation and sustainability of trees, common in highaltitude grasslands $[7,28]$, compared to histic horizons of histic litholic entisols observed by Portes [25]. Therefore, in these environments, geomorphic features and climate control the soils, which regulate the occurrence of forest or grassland vegetation.

3.5. Carbon Stocks in Upper Montane Soils of Caratuva Peak. The soil carbon stocks in the high-altitude grasslands ranged from 195.4 to $512.5 \mathrm{Mg} \mathrm{Cha}^{-1}$ (mean \pm standard error: $260.7 \pm$ $32.7 \mathrm{MgCha}^{-1}$ for the lithic histosols near the ridge and $462.7 \pm 26.8 \mathrm{MgCha}^{-1}$ for the typic histosols downslope). The soil carbon storage estimated for the upper montane cloud/rain forest on regosols and gleysols varied from 93.9 to $220.6 \mathrm{Mg} \mathrm{Cha}^{-1}\left(158.6 \pm 24.9 \mathrm{Mg} \mathrm{Cha}^{-1}\right)$. The storage was statistically higher in grassland than in forest $(U$ test; $P<$ 0.05; Table 3).

Based on soil data from Serra da Igreja [7], the potential C stocks estimated for the soils of high-altitude grasslands and the upper montane dense cloud/rain forest in the state of Paraná, southern Brazil, were $0.54 \times 10^{6} \mathrm{MgC}$ and 1.25 $\times 10^{6} \mathrm{MgC}$, respectively. These values, particularly grassland stocks, were in line with the observations presented in this study. Specifically, we found that potential C stocks from high-altitude grasslands and Upper montane dense rainforest in the state of Paraná based on Caratuva Peak soil data and PRO ATLÂNTICA vegetation cover data [45] contained 0.59 $\times 10^{6} \mathrm{MgC}$ and $0.91 \times 10^{6} \mathrm{MgC}$, respectively. This indicates that although these upper montane environments are separated by about $500 \mathrm{~m}$ a.s.l. (Caratuva Peak stretches between 1790 and $1840 \mathrm{~m}$ s.n.m and Igreja Mountain Range between 1325 and $1335 \mathrm{~m}$ s.n.m.), similar chemical characteristics, physical characteristics, and levels of carbon stocks were observed.

The small differences could be caused by many factors including geomorphic position (slope types, declivity, etc.), temperature differences, rainfall levels, variable decomposition rates, and primary productivity. Larger and more detailed samplings are needed to identify the main factors. Thus, the presence of histic horizons rather than altitude consideration could be a better parameter to help determine sites of preservation (in discussion for the current Brazilian Forest Code), as the same type of upper montane vegetation is commonly found below $1800 \mathrm{~m}$ a.s.l. in southern Brazil.

Because the Ibitiraquire Mountain Range was estimated to have 790 ha of high-altitude grasslands [44], the soil C stocks for these ecosystems range from $0.138 \times 10^{6} \mathrm{MgC}$ to 


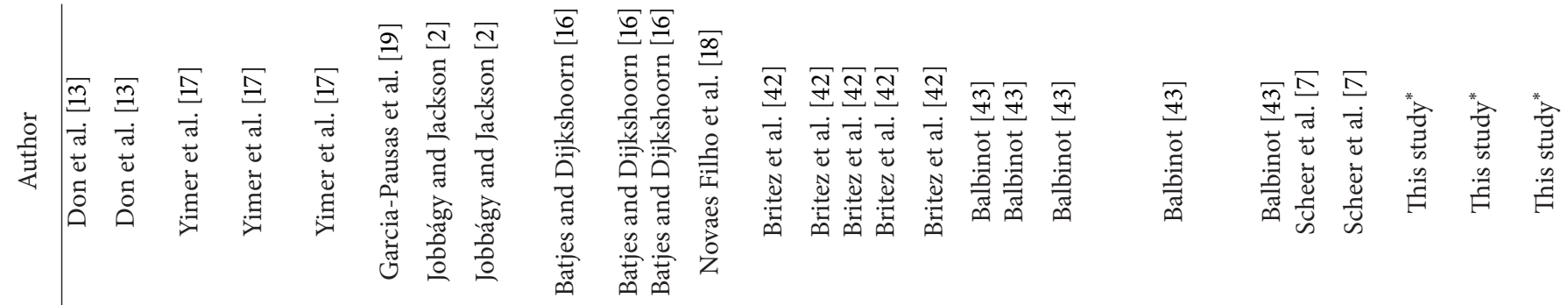

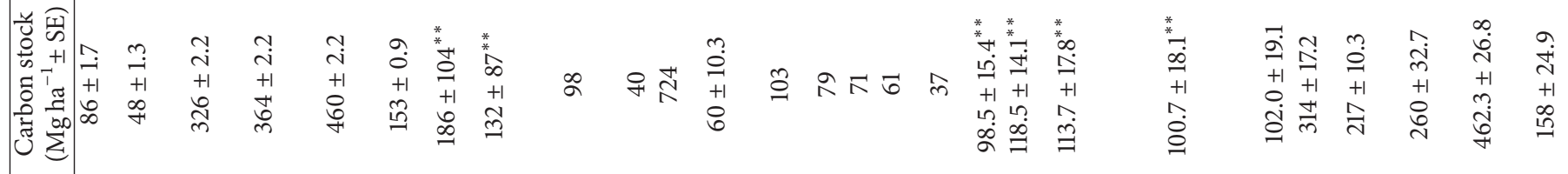

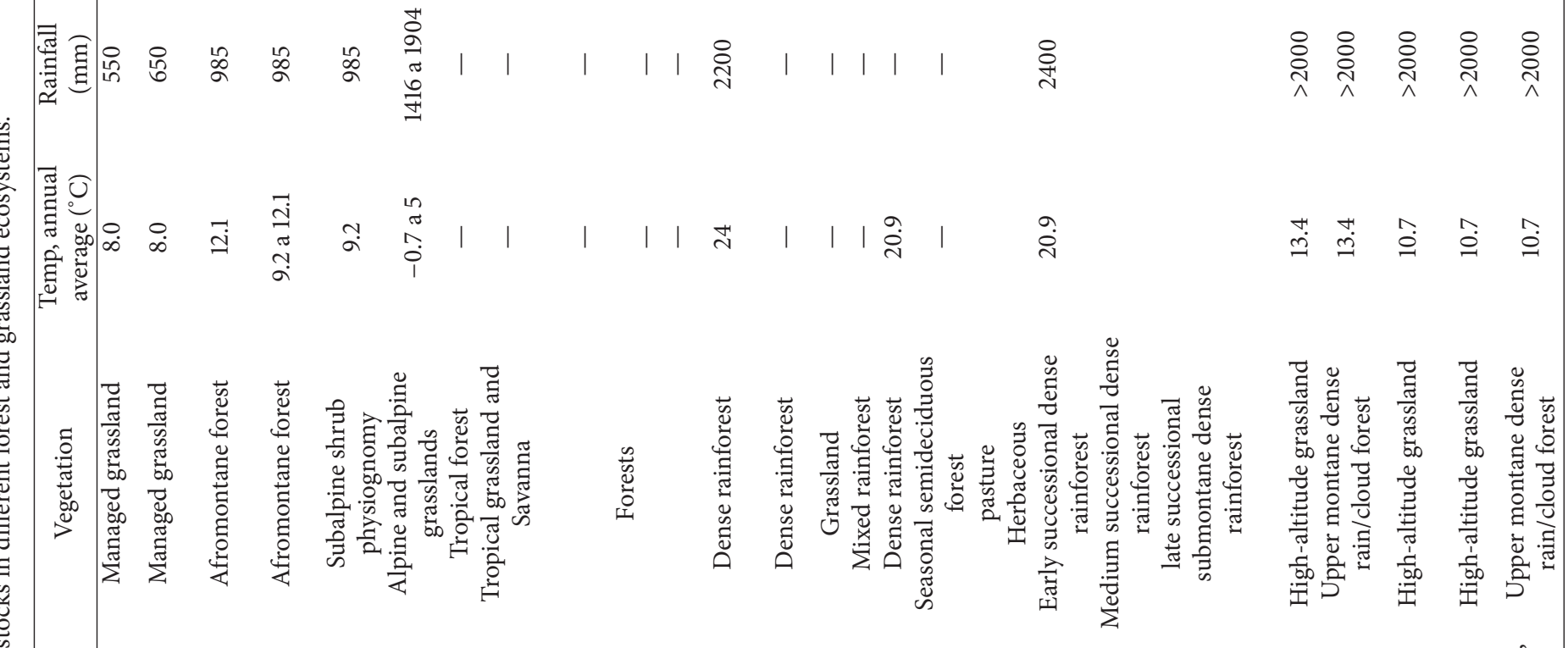

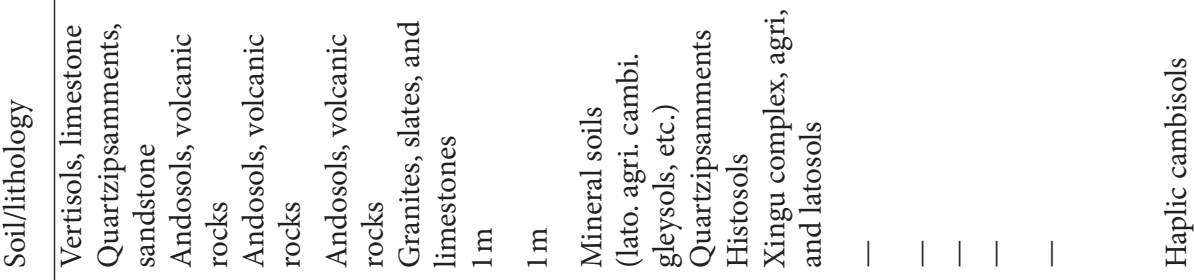

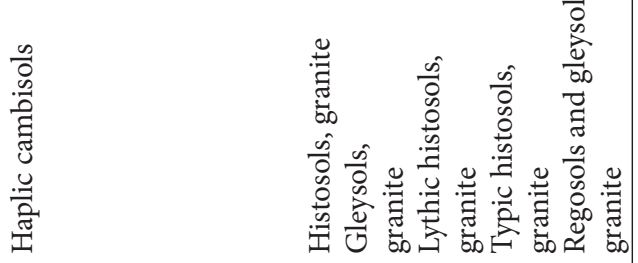

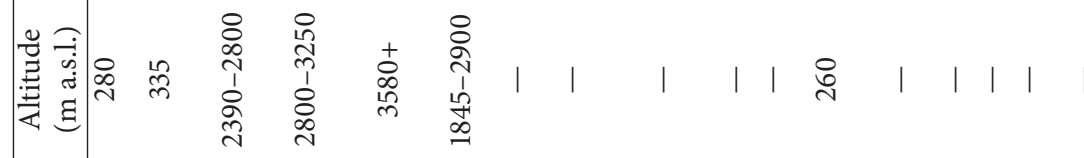

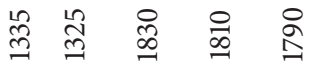

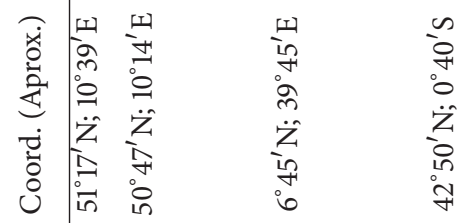

3
3
$\infty$
$\infty$
$\infty$
$i n$
$i \infty$
$\infty$
$\infty$
0
0

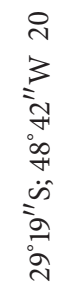

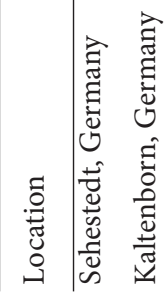

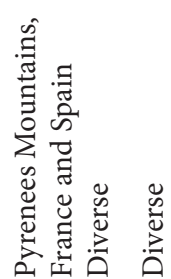

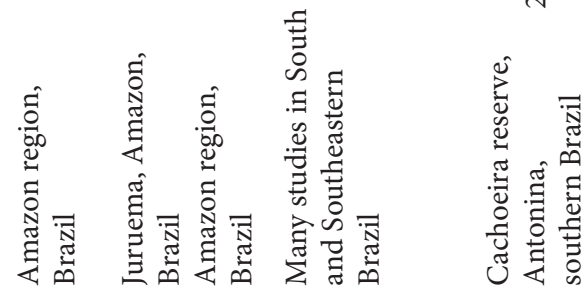
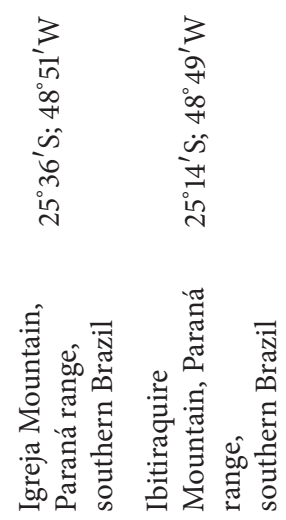
$0.361 \times 10^{6} \mathrm{Mg}$ C. Additionally, the studies at the Sea Mountain Range of southern Brazil revealed that the soil carbon stocks by unit area in high-altitude grasslands are higher than the stocks of the upper montane forests. Moreover, both stocks are considerably higher when compared to soils of other ecosystems (Table 4). Therefore, to obtain precise estimates, more surveys are needed.

Differences in C stocks from various mountain aspects, topographic/geomorphic positions, and parent materials are very common in the same mountain $[17,19]$. Although the $\mathrm{C}$ concentrations are 30 -fold lower in mineral horizons than histic horizons of upper montane rain forests, they comprise almost half (46\%) of the carbon soil stocks. This is explained by the 10-fold greater density of mineral horizons compared to histic horizons (Table 3 ). However, the mineral horizons of the observed histosols in grasslands contribute between 0 and $8 \%$ of total soil carbon due to their small thickness and to lower densities.

3.6. Upper Montane Soil Carbon Stocks and the Carbon Storage in Above-Ground Forest Biomass. The mean values of soil carbon stocks of high-altitude grasslands and upper montane forests of the Igreja Mountain Range were 314.7 and $217.2 \mathrm{MgCha}^{-1}$, respectively, according to Scheer et al. [7], and the corresponding estimates for Caratuva Peak were $361.4 \pm 48.9$ and $158.6 \pm 24.9 \mathrm{MgCha}^{-1}$. These estimates were higher than the highest estimates for the above-ground biomass of submontane rainforests (about $200 \mathrm{MgCha}^{-1}$, mean near $120 \mathrm{MgCha}^{-1}$ ), which represents the highest above-ground productivity among the Atlantic Forests [52, 53].

Based on many forest structure surveys of the Atlantic Forest in the state of Paraná [42], carbon stocks in aboveground biomass are estimated at $26 \mathrm{MgCha}^{-1}$ (early secondary successional stage) and $153 \mathrm{Mg} \mathrm{C} \mathrm{ha}^{-1}$ (mature forest). As stated previously, such information highlights the great importance of upper montane soil carbon stocks. Namely, the high-altitude grassland soils have the capacity to stock more than twice the above-ground biomass of the lower montane Atlantic rainforest, where the highest primary productivity among the forests of southern and southeastern of Brazil is found.

3.7. Upper Montane Soil Water Retention Potential in Caratuva Peak. The high-saturated permeability of the histic horizons (reaching $319.5 \mathrm{~cm} \mathrm{~h}^{-1}$, Table 3) was considerably reduced to 3 to $7.2 \mathrm{~cm} \mathrm{~h}^{-1}$ with depth, favoring higher water retention in the soil volume. The hemic and fibric characteristics of superficial horizons, which include their low densities $\left(0.108\right.$ to $\left.0.117 \mathrm{~kg} \mathrm{dm}^{-3}\right)$, high macroporosity and aeration, and considerable pore connectivity, contribute to very high permeability. Although the histic horizons had high water retention capacity, the available water concentrations were low (Table 3). The gleyic horizons, such as the Big horizon representing regosols, showed lower total porosities. They also presented with lower percentage of macropores leading to lower aeration capacity and saturated permeability, which is related to structural and textural changes (Table 3). Like the estimated carbon stocks, the potential water retention capacities of the histosols (profiles 1 and 2; 2048 and $4976 \mathrm{~m}^{3} \mathrm{ha}^{-1}$, resp.) were similar to those calculated for the Igreja Mountain Range [7]. The regosols of the forest showed a capacity of $3188 \mathrm{~m}^{3} \mathrm{ha}^{-1}$.

\section{Conclusions}

Soils from the ridge of the Caratuva, as in other upper montane environments of southern Brazil, are dystrophic, extremely acidic, and highly saturated with $\mathrm{Al}$ and TOC. Upper montane forests of the Sea Mountain Range of southern Brazil were strongly established by physical impacts from valleys and peaks. Additionally, these forests were influenced by slopes susceptible to higher action of morphogenetic processes, which result in soils with mineral horizons containing higher amounts of clay (such as gleysols and regosols). The high density of these horizons also promoted better conditions to the development of tree species. Therefore, in the upper montane environments, the thickening of mineral horizons and the thinning of histic horizons contribute to the growth of forests. High-altitude grasslands occupy ridges of folic and haplic histosols found on divergent convex ramps, resulting in thicker histic horizons. The low density and lack of consistency of these horizons associated with seasonal hydromorphy and strong winds hinder the development of forests in these environments.

Considering the studies at Sea Mountain Range of southern Brazil, the soil carbon stocks in the high-altitude grasslands are higher by unit area than the stocks of the upper montane forests. However, both values are higher, when compared to soils from other ecosystems including the aboveground biomass of submontane dense rainforests, which exhibited high primary productivity. The high potential of soil water retention of upper montane environments is strongly related to the high total porosities of histic horizons associated with the gleyic horizons. These characteristics, in addition to the filter capacity of these soils, must also be recognized as environmentally functional and worthy of preservation.

\section{Acknowledgments}

The authors would like to thank many colleagues for their substantial help in the field: Marcos Rachwal, Bruno Miranda, Eduardo Lozano, Letícia Sousa, Yury Vashchenko, Anette Bonnet, and Marcia de Lima. This research was supported by the Fundação Grupo Boticário de Proteção à Natureza (0800_2008_2). The authors are greatly indebted to the Sociedade Chauá and Programa de Pós-Graduação em Engenharia Florestal da UFPR.

\section{References}

[1] N. H. Batjes, "Total carbon and nitrogen in the soils of the world," European Journal of Soil Science, vol. 47, no. 2, pp. 151163, 1996. 
[2] E. G. Jobbágy and R. B. Jackson, "The vertical distribution of soil organic carbon and its relation to climate and vegetation," Ecological Applications, vol. 10, no. 2, pp. 423-436, 2000.

[3] M. Bernoux, M. C. S. Carvalho, B. Volkoff, and C. C. Cerri, "Brazil's soil carbon stocks," Soil Science Society of America Journal, vol. 66, no. 3, pp. 888-896, 2002.

[4] K. Kitayama and S. I. Aiba, "Ecosystem structure and productivity of tropical rain forests along altitudinal gradients with contrasting soil phosphorus pools on Mount Kinabalu,Borneo," Borneo. Journal of Ecology, vol. 90, no. 1, pp. 37-51, 2002.

[5] M. Zimmermann, P. Meir, M. I. Bird, Y. Malhi, and A. J. Q. Ccahuana, "Climate dependence of heterotrophic soil respiration from a soil-translocation experiment along a $3000 \mathrm{~m}$ tropical forest altitudinal gradient," European Journal of Soil Science, vol. 60, no. 6, pp. 895-906, 2009.

[6] L. Roman, F. N. Scatena, and L. A. Bruijnzeel, "Global and local variations in tropical montane cloud forest soils," in Tropical Montane Cloud Forests: Science For Conservation and Management, L. A. Bruijnzeel, F. N. Scatena, and L. Hamilton, Eds., Cambridge University Press, Cambridge, UK, 2010.

[7] M. B. Scheer, G. R. Curcio, and C. V. Roderjan, "Environmental functionalities of upper montane soils in Serra da Igreja, Southern Brazil," Revista Brasileira de Ciencia do Solo, vol. 35, no. 4, pp. 1113-1126, 2011.

[8] L. A. Bruijnzeel, "Hydrology of tropical montane cloud forests: a reassessment," in Proceedings of the Second International Colloquium, J. S. Gladwell, Ed., pp. 353-383, UNESCO, Paris, France, 2000.

[9] F. N. B. Simas, C. E. G. R. Schaefer, E. I. Fernandes Filho, A. C. Chagas, and P. C. Brandão, "Chemistry, mineralogy and micropedology of highland soils on crystalline rocks of Serra da Mantiqueira, Southeastern Brazil," Geoderma, vol. 125, no. 3-4, pp. 187-201, 2005.

[10] V. M. Benites, C. E. G. R. Schaefer, F. N. B. Simas, and H. G. Santos, "Soils associated with rock outcrops in the Brazilian mountain ranges Mantiqueira and Espinhaço," Revista Brasileira de Botanica, vol. 30, no. 4, pp. 569-577, 2007.

[11] W. Zech, N. Senesi, G. Guggenberger et al., "Factors controlling humification and mineralization of soil organic matter in the tropics," Geoderma, vol. 79, no. 1-4, pp. 117-161, 1997.

[12] B. Volkoff, C. C. Cerri, and A. J. Melfi, "Húmus and mineralogy of superficial horizons of three soils of upland grass fields of Minas Gerais, Paraná and Santa Catarina states, Brazil," Revista Brasileira de Ciencia do Solo, vol. 8, pp. 277-283, 1984.

[13] A. Don, J. Schumacher, M. Scherer-Lorenzen, T. Scholten, and E. D. Schulze, "Spatial and vertical variation of soil carbon at two grassland sites-Implications for measuring soil carbon stocks," Geoderma, vol. 141, no. 3-4, pp. 272-282, 2007.

[14] M. L. Martínez, O. Pérez-Maqueo, G. Vázquez et al., "Effects of land use change on biodiversity and ecosystem services in tropical montane cloud forests of Mexico," Forest Ecology and Management, vol. 258, no. 9, pp. 1856-1863, 2009.

[15] L. A. Bruijnzeel and J. Proctor, "Hydrology and biogeochemistry of tropical montane cloud forests: what do we really know?" in Tropical Montane Cloud Forests, Hamilton, L. S et al., Eds., pp. 38-78, Springer, New York, NY, USA, 1995.

[16] N. H. Batjes and J. A. Dijkshoorn, "Carbon and nitrogen stocks in the soils of the amazon region," Geoderma, vol. 89, no. 3-4, pp. 273-286, 1999.

[17] F. Yimer, S. Ledin, and A. Abdelkadir, "Soil organic carbon and total nitrogen stocks as affected by topographic aspect and vegetation in the Bale Mountains, Ethiopia," Geoderma, vol.135, pp. 335-344, 2006.

[18] J. P. N. Novaes Filho, E. C. Selva, E. G. Couto, J. Lehmann, M. S. Johnson, and S. J. Riha, "Spatial distribution of soil carbon under primary forest cover in southern Amazônia," Sociedade de Investigações Florestais, vol. 31, no. 1, pp. 83-92, 2007.

[19] J. Garcia-Pausas, P. Casals, L. Camarero et al., "Soil organic carbon storage in mountain grasslands of the Pyrenees: Effects of climate and topography," Biogeochemistry, vol. 82, no. 3, pp. 279-289, 2007.

[20] A. Becker, C. Körner, J. J. Brun, A. Guisan, and U. Tappeiner, "Ecological and land use studies along elevational gradients," Mountain Research and Development, vol. 27, no. 1, pp. 58-65, 2007.

[21] G. A. Arteaga, N. E. G. Calderón, P. V. Krasilnikov, S. N. Sedov, V. O. Targulian, and N. V. Rosas, "Soil altitudinal sequence on base-poor parent material in a montane cloud forest in Sierra Juárez, Southern Mexico," Geoderma, vol. 144, no. 3-4, pp. 593612, 2008.

[22] C. V. Roderjan, A floresta ombrafila densa altomontana no morro Anhangava. Quatro Barras. PR: aspectos climlticos, pedolagicos e fitossociolagicos [Ph.D. thesis], Universidade Federal do Paraná, 1994.

[23] N. L. B. Ghani, Caracterização morfológica. física. química. mineralógica. gênese e classificação de solos altimontanos derivados de riólito e migmatito da Serra do Mar. PR [M.S. thesis], Universidade Federal do Paraná, 1996.

[24] M. R. L. Rocha, Caracterização fitossociológica e pedológica de uma floresta ombrófila densa no parque estadual do pico do Marumbi-Morretes. PR [M.S. thesis], Universidade Federal do Paraná, 1999.

[25] M. C. G. de O. Portes, Deposição de serapilheira e decomposição foliar em floresta ombrófila densa altomontana. Morro Anhangava. Serra da Baitaca. Quatro Barras. PR [M.S. thesis], Universidade Federal do Paraná, 2000.

[26] D. B. Falkenberg, Matinhas nebulares e vegetação rupícola dos Aparados da Serra Geral (SC/RS). sul do Brazil [Ph.D. thesis], Universidade de Campinas, 2003.

[27] C. Wisniewski, P. B. Tempesta, and V. M. R. Rodrigues, "Solos e vegetação em uma topossequência do morro Mãe Catira. alto da Serra da Graciosa. Morretes PR," in Proceedings of the 30th Congresso Brasileiro de Ciência do Solo, Sociedade Brasileira de Ciências do Solo, Viçosa, Brazil, 2005.

[28] Y. Vashchenko, R. P. Piovesan, M. R. Lima, and N. Favaretto, "Solos e Vegetação dos Picos Camacuã. Camapuã e TucumCampina Grande Do Sul-PR," Scientia Agraria, vol. 8, no. 4, pp. 411-419, 2007.

[29] A. C. Silva, I. Horák, A. M. Cortizas et al., "Peat bogs of the serra do espinhaço meridional-Minas Gerais, Brazil. ICharacterization and classification," Revista Brasileira de Ciencia do Solo, vol. 33, no. 5, pp. 1385-1398, 2009.

[30] Mineropar Minerais do Paraná S. A., Atlas Geológico do Estado do Paraná, Curitiba, Brazil, 2001.

[31] Melo, P. C. F. Giannini, and L. C. R. Pessenda, "Gênese e Evolução da Lagoa Dourada. Ponta Grossa. PR," Revista do Instituto Geológico, vol. 21, no. 2, pp. 17-31, 2000.

[32] A. Y. Mocochinski, Campos de altitude na serra do mar paranaense: aspectos florísticos e estruturais [M.S. thesis], Universidade Federal do Paraná, 2006.

[33] A. Y. Mocochinski and M. B. Scheer, "Campos de altitude na serra do mar paranaense: aspectos florísticos," Revista Floresta, vol. 38, no. 4, pp. 625-640, 2008. 
[34] M. B. Scheer and A. Y. Mocochinski, "Floristic composition of four tropical upper montane rain forests in Southern Brazil," Biota Neotropica, vol. 9, no. 2, pp. 51-69, 2009.

[35] M. B. Scheer and A. Y. Mocochinski, "Tree component structure of tropical upper montane rain forests in Southern Brazil," Acta Botanica Brasilica, vol. 25, no. 4, pp. 735-750, 2011.

[36] C. V. Roderjan and L. Grodski, "Acompanhamento meteorológico em um ambiente de Floresta Ombrófila Densa Altomontana no morro Anhangava. Mun. De Quatro Barras. PR," Cadernos da Biodiversidade, vol. 2, no. 1, pp. 27-34, 1999.

[37] R. Maack, Geografia Física do Estado do Paraná, Imprensa Oficial, Curitiba, Brazil, 2002.

[38] R. D. Santos, R. C. Lemos, H. G. Santos, J. C. Ker, and L. H. C. Anjos, Manual de Descrição e Coleta de Solo no Campo, Sociedade Brasileira de Ciências do Solo, Viçosa, Brazil, 2005.

[39] Empresa Brasileira de Pesquisa Agropecuária, Sistema Brasileiro de Classificação de Solos, EMBRAPA, Rio de Janeiro, Brazil, 2nd edition, 2006.

[40] Empresa Brasileira de Pesquisa Agropecuária, Manual de Métodos de Análises de Solos, EMBRAPA, Rio de Janeiro, Brazil, 1997.

[41] C. L. Prevedello, Física do Solo: Com Prolemas Resolvidos, Curitiba, Brazil, 1996.

[42] R. M. Britez, M. Borgo, G. Tiepolo, A. Ferreti, M. Calmon, and R. Higa, Estoque e Incremento de Carbono em Florestas e Povoamentos de Espécies Arbóreas Com ênfase na Floresta Atlântica do Sul do Brazil, EMBRAPA, Colombo, Sri Lanka, 2006.

[43] R. Balbinot, Carbono nitrogênio e razões isotópicas ${ }^{13} \mathrm{C} e{ }^{15} \mathrm{~N}$ no solo e vegetação de estágios sucessionais de Floresta Ombrófila Densa Submontana [Ph.D. thesis], Universidade Federal do Paraná, 2009.

[44] C. V. Roderjan, Caracterização da vegetação dos Refúgios Vegetacionais Altomontanos nas serras dos órgãos e do Capivari no Estado do Paraná, Relatório Técnico do CNPq., Curitiba, Brazil, 1999.

[45] Programa de Proteção da Floresta Atlântica-PRÓATLÂNTICA, Projeto Carta Geológica, Cartas: MI-2844-2 Ariri. MI-2843-1 Represa do Capivari. MI-2843-3 Morretes. MI2858-1 Mundo Novo e MI-2858-3 Pedra Branca do Araraquara, Escala 1:50000, SEMA, Curitiba, Brazil, 2002.

[46] V. M. Benites, A. N. Caiafa, E. S. Mendonça, C. E. G. R. Schaeffer, and J. C. Ker, "Soil and vegetation on the high altitude rocky complexes of the Mantiqueira and Espinhaço mountain," Revista Floresta e Ambiente, vol. 10, pp. 76-85, 2003.

[47] V. M. Benites, E. S. Mendonça, C. E. G. R. Schaefer, E. H. Novotny, E. L. Reis, and J. C. Ker, "Properties of black soil humic acids from high altitude rocky complexes in Brazil," Geoderma, vol. 127, no. 1-2, pp. 104-113, 2005.

[48] B. M. Serrat, K. I. Krieger, and A. C. V. Motta, "Considerações sobre a interpretação de análise de solos," in Recomendações de Manejo do Solo: Aspectos Tecnológicos e Metodológicos, M. R. Lima et al., Ed., pp. 125-143, UFPR, Curitiba, Brazil, 2006.

[49] L. S. Hamilton, J. O. Juvik, and F. N. Scatena, "The Puerto Rico tropical cloud forest symposium: introduction and workshop synthesis," in Tropical Montane Cloud Forests, L. S. Hamilton et al., Ed., pp. 1-23, Springer, New York, NY, USA, 1995.

[50] F. J. Stevenson, Humus Chemistry: Genesis, Composition, Reactions, John Wiley \& Sons, New York, NY, USA, 1982.

[51] M. A. Pavan, "Alumínio em solos ácidos do Paraná: relação entre o alumínio não-trocável, trocável e solúvel, com o $\mathrm{pH}$,
CTC, porcentagem de saturação de Al e matéria orgânica," Revista Brasileira de Ciencia do Solo, vol. 7, pp. 39-46, 1983.

[52] S. A. Vieira, L. F. Alves, M. Aidar et al., "Estimation of biomass and carbon stocks: the case of the Atlantic Forest," Biota Neotropica, vol. 8, no. 2, pp. 21-29, 2008.

[53] G. Tiepolo, M. Calmon, and A. R. Feretti, "Measuring and monitoring carbon stocks at the guaraqueçaba climate action project, Paraná, Brazil," in International Symposium on Forest Carbon Sequestration and Monitoring, vol. 153, pp. 98-115, Taiwan Forestry Research Institute, 2002. 

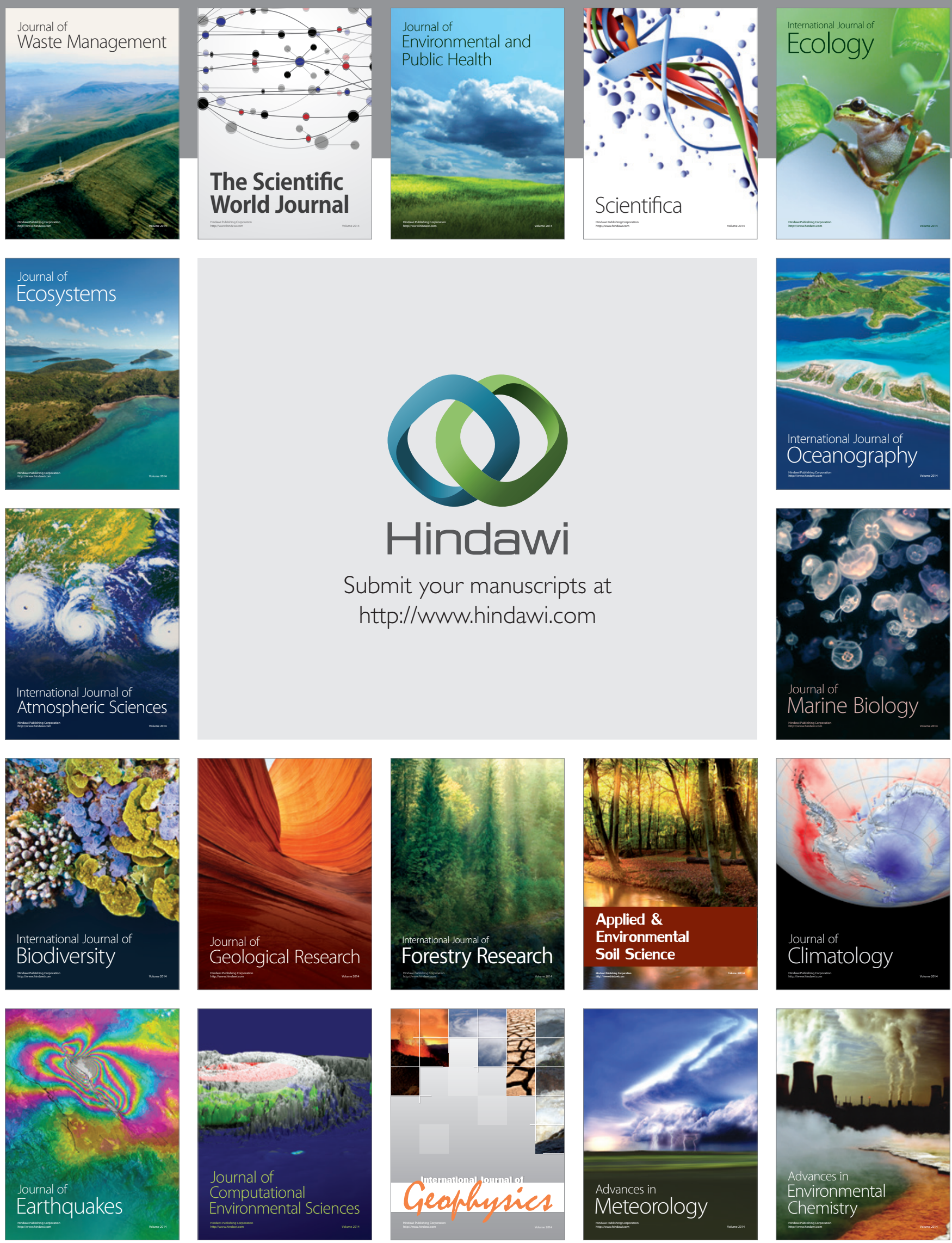